\section{CHARACTERIZATION OF THERMOSTABLE BETA- 1,4-GALACTANASE AND ITS APPLICATION IN HYDROLYSIS OF PECTIN FROM SWEET POTATO (IPOMOEA BATATAS (L.) LAM) PEELS}

Noor Faizah Ismail ${ }^{a, b}$, Dayang Norulfairuz Abang Zaidela,c*, Mohd Noor Mat Isa

aschool of Chemical and Energy Engineering, Faculty of Engineering, Universiti Teknologi Malaysia, 81310 UTM Johor Bahru, Johor, Malaysia

bFisheries Research Institute, FRI Glami Lemi, 71650 Titi, Negeri Sembilan, Malaysia

Institute of Bioproduct Development, Faculty of Engineering, Universiti Teknologi Malaysia, 81310 UTM Johor Bahru, Johor, Malaysia 'Malaysia Genome Institute, 43000 Kajang, Selangor, Malaysia
Article history

Received

21 June 2021

Received in revised form

12 July 2021

Accepted

26 July 2021

Published online

20 August 2021

*Corresponding author dnorulfairuz@utm.my

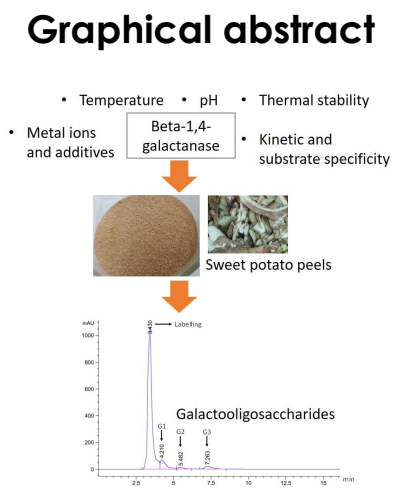

\begin{abstract}
Galactooligosaccharides (GOS) synthesis has received much attention due to its prebiotic function. Beta-1,4-galactanase responsible for the hydrolysis of galactan plays an important role in producing GOS from biodegradation of this pectin component. In this study, beta-1,4galactanase (BgcGC) from a thermophilic Geobacillus mahadii Geo-05 was heterologously expressed in Escherichia coli (E. coli) and characterized. The optimum temperature of BgcGC was at $60^{\circ} \mathrm{C}$ and stable from $20-60^{\circ} \mathrm{C}$ while optimum $\mathrm{pH}$ was at 6 and stable from $\mathrm{pH} 4-10$. BgcGC showed high catalytic efficiency towards potato galactan $\left(873.8 \mathrm{ml} \mathrm{mg}^{-1} \mathrm{~s}^{-1}\right)$ and lupin galactan (1694.4 $\left.\mathrm{ml} \mathrm{mg}^{-1} \mathrm{~s}^{-1}\right)$. The activity of BgcGC was not significantly affected with the presence of $100 \mathrm{mM} \mathrm{K}$, Tween-20 and 2-mercaptoethanol. Application of BgcGC towards pectin-containing galactan oligomer extracted from sweet potato peels resulted in galactose and GOS synthesis as revealed by high performance liquid chromatography analysis. Thus, this enzyme has a potential to be one of the enzyme candidates involves in pectin complex degradation to produce GOS.
\end{abstract}

Keywords: Beta-1,4-galactanase, thermophilic, pectin, galactan, galactooligosaccharide

\begin{abstract}
Abstrak
Sintesis galaktooligosakarida (GOS) telah mendapat banyak perhatian disebabkan fungsi prebiotiknya. Beta-1,4-galaktanase bertanggungjawab terhadap hidrolisis galaktan memainkan peranan penting dalam penghasilan GOS daripada biodegradasi komponen pektin ini. Di dalam kajian ini, beta-1,4-galaktanase (BgcGC) daripada Geobacillus mahadii Geo-05 termofilik telah diekspres secara heterologi di dalam Escherichia coli (E. coli) dan dicirikan. Suhu optima BgcGC adalah pada $60^{\circ} \mathrm{C}$ dan stabil antara $20-60^{\circ} \mathrm{C}$ manakala $\mathrm{pH}$ optima ialah pada $\mathrm{pH} 6$ dan stabil antara $\mathrm{pH}$ 4-10. BgcGC menunjukkan keefisienan pemangkin yang tinggi terhadap galaktan kentang $\left(873.8 \mathrm{ml} \mathrm{mg}^{-1} \mathrm{~s}^{-1}\right)$ dan galaktan lupin $\left(1694.4 \mathrm{ml} \mathrm{mg}^{-1} \mathrm{~s}^{-1}\right)$. Aktiviti BgcGC tidak begitu terkesan dengan kehadiran 100 mM K+, Tween-20 dan 2-merkaptoetanol. Aplikasi BgcGC terhadap pektin yang mengandungi polimer galaktan ekstraksi daripada kulit ubi keledek menghasilkan galaktan dan GOS sebagai produk hidrolisis seperti yang ditunjukkan oleh analisis kromatografi cecair berprestasi tinggi. Oleh itu, enzim ini berpotensi untuk menjadi salah satu calon enzim yang terlibat dalam degradasi kompleks pektin untuk menghasilkan GOS.
\end{abstract}

Kata kunci: Beta-1,4-galaktanase, termofilik, pektin, galaktan, galaktooligosakarida

(C) 2021 Penerbit UTM Press. All rights reserved 


\subsection{INTRODUCTION}

Carbohydrate is one of the most important biomolecules commonly found in nature. It serves as energy storage, metabolic intermediates and becoming a structural element in the living cells. To keep its function, an enzyme or a catalyst is important to accelerate the reaction or mechanism involved. Hydrolysis of carbohydrate assisted by a group of the enzyme is known as glycosyl hydrolase $(\mathrm{GH})$.

$\mathrm{GH}$ also called glycosidase (EC 3.2.1.-), is a widespread group of enzymes responsible for the cleavage of glycosidic bond in carbohydrate molecule. Its prominent application in degrading biomass components such as cellulose, hemicellulose, pectin and starch make it an outstanding class of enzyme to be studied. A dedicated database for the carbohydrate enzyme named as CarbohydrateActive Enzymes database (CAZy; http://www.cazy.org) has been established to gather information regarding the most influential enzymes in the universe [1]. GH are classified into families according to their amino acid sequence similarities which reflect the protein folding. The vast applications of glycosidases ranging from the harnessing of plant biomass degradation to their roles in human physiology and health, has triggered a large scientific group with an interest in glycosidase chemistry.

Beta-1,4-galactanase (EC 3.2.1.89) is a $\mathrm{GH}$ under family 53 which catalyze hydrolysis reaction of beta-1,4-galactan in an endo-mode action. It has been applied in pectic polysaccharide degradation and mechanism of action [2,3]. The action of beta1,4-galactanase together with other enzymes has been proven to facilitate the hydrolysis of complex plant biomass $[4,5]$. To fulfill the industrial need, the enzyme property to withstand high temperature gives an advantage in reducing the chance for microbial growth and improving solubility of substrate at high concentration.

Hydrolysis reaction of beta-1,4-galactanase resulted in the galactooligosaccharide (GOS) synthesis. GOS has been widely used in human milk formula due to its prebiotic role and it is mainly obtained from transglycosylation reaction of betagalactosidase towards lactose $[6,7,8]$. However, in recent years, galactan from pectin extract has been studied for the GOS synthesis [4]. GOS produced from galactan has been proven to possess prebiotic effect on the human gut microflora such as Bacteroides thetaiotaomicron, Lactobacillus and Bifidobacterium sp. [3, 9, 10].

Galactan can be found in a heteropolysaccharide structure of pectin which comprises of three main regions known as homogalacturonan, rhamnogalacturonan I and rhamnogalacturonan II [11, 12]. Meanwhile, pectin polysaccharides are abundantly found in primary plant cell wall of dicotyledon which makes it becomes the emerging source of galactan that is being explored as an alternative substrate to lactose for GOS synthesis.

Depolymerisation of pectin requires physical, chemical or enzymatic process [13]. Enzyme reaction provides mild conditions and usually safer than chemical reaction, thus become favorable in biodegradation of biomass like pectin. The incorporation of thermostable enzyme may be essential as pectin operates at high temperature due to its viscosity property [14]. This study described the biochemical characterization of beta-1,4galactanase and its potential application to be used in hydrolysis of pectin from sweet potato (Ipomoea batatas (L.) Lam) peels to produce GOS.

\subsection{METHODOLOGY}

\subsection{Bacterial Strains, Plasmid and Chemicals}

Beta-1,4-galactanase gene from Geobacillus mahadii Geo-05 (GenBank accession number: ARB18040.1) was synthesized with codon-optimized sequence by GenScript USA Inc and cloned into pCold-I (Takara, USA) as the expression vector. The constructed plasmid was named as BgcGC and transformed into E. coli JM109 and E. coli BL21 (DE3) (Promega, USA) as the cloning and expression host, respectively. The transformed cells were grown in Luria Bertani medium supplemented with $100 \mu \mathrm{g} / \mathrm{ml}$ ampicillin and incubated for 16-18 hours with $200 \mathrm{rpm}$ shaking at $37^{\circ} \mathrm{C}$ for growth. Chemicals used in this study were either analytical or HPLC grade from Sigma Aldrich (Missouri, USA), Merck (Darmstadt, Germany) and Thermo Fisher Scientific (Massachusetts, USA).

\subsection{Enzyme Expression and Purification}

Expression of BgcGC was modulated as per mentioned in the plasmid manual employed in this study. BgcGC was induced with $0.5 \mathrm{mM}$ isopropyl beta-D-1-thiogalactopyranoside (IPTG) when $\mathrm{OD}_{600}$ reached $\sim 0.5$ and switched to $20^{\circ} \mathrm{C}$ incubation for 8 hours. An $800 \mathrm{ml}$ of cell culture were harvested by centrifugation at $3,220 \times \mathrm{g}, 30 \mathrm{~min}$ at $4^{\circ} \mathrm{C}$ using $250 \mathrm{ml}$ conical bottle in swing bucket operated by Eppendorf Centrifuge 5810 R (Hamburg, Germany). The cell pellets were suspended in $5 \%(\mathrm{v} / \mathrm{v})$ of binding buffer $(150 \mathrm{mM}$ Tris, $25 \mathrm{mM} \mathrm{NaCl}, 20 \mathrm{mM} 2-$ mercaptoethanol and $20 \%$ glycerol, $\mathrm{pH} 8$ ) from the volume of culture followed by sonication in an ice bath. A $0.5 \mathrm{mM}$ phenylmethanesulfonyl fluoride (PMSF) was added to the suspension before and after sonicated to avoid protein degradation by proteases. The cell debris was removed by centrifugation at $9509 \times \mathrm{g}$ for $30 \mathrm{~min}$ at $4^{\circ} \mathrm{C}$.

The supernatant constituting the enzyme crude extract was loaded into a self-packed Ni Sepharose 6 Fast Flow (GE Healthcare, UK) column. Purification 
procedure was guided by the manufacturer's manual of resin used in this study [15]. Binding buffer was applied to the column before elution buffer (150 $\mathrm{mM}$ Tris, $25 \mathrm{mM} \mathrm{NaCl}$ and $300 \mathrm{mM}$ imidazole, $\mathrm{pH}$ 8) was loaded into the column to recover the $\mathrm{Ni}$ binding protein.

Second step purification was done using HiTrap Q HP, $5 \mathrm{ml}$ (GE Healthcare, UK) with an ÄKTAPrime Plus Purification System (GE Healthcare, UK). Lhistidine buffer (20 mM L-histidine, $\mathrm{pH}$ 6) was applied to the column while $20 \mathrm{mM}$ L-histidine buffer containing $1 \mathrm{M} \mathrm{NaCl}(\mathrm{pH}$ 6) was used to elute the protein using gradient mode. All the procedures described were performed at $4^{\circ} \mathrm{C}$.

\subsection{Beta-1,4-galactanase and Protein Assay}

Beta-1,4-galactanase assay procedure using 4hydroxybenzoic acid hydrazide (PAHBAH) reagent was adapted from the previous studies [10, 16]. The hydrolysis activity of BgcGC was measured by incubating $50 \mu \mathrm{l}$ of diluted enzyme in $125 \mu \mathrm{l}$ of $1 \%$ (w/v) potato galactan from Megazyme (Bray, Ireland) in citrate-phosphate buffer, $\mathrm{pH} 6.0$ (Mlilvaine buffer, $0.1 \mathrm{M}$ citric acid and $0.2 \mathrm{M}$ disodium hydrogen phosphate). The enzyme mixture was then incubated at $60^{\circ} \mathrm{C}$ for $30 \mathrm{~min}$. A $5 \mu \mathrm{l}$ of the reaction mixture was taken out and added into $1.5 \mathrm{ml}$ of $\mathrm{PAHBAH}$ reagent and boiled for $5 \mathrm{~min}$ to stop the reaction. The absorbance was read at $410 \mathrm{~nm}$. One unit of enzyme activity was defined as the amount of enzyme required to produce $1 \mu \mathrm{mol}$ of galactose per min under experimental conditions. The protein concentration was measured by the Bradford method with bovine serum albumin as a standard [17].

\subsection{Biochemical Characterization, Substrate Specificity and Enzyme Kinetics}

The optimum temperature for the purified BgcGC was measured by conducting assay at different temperature ranging from 20 to $90^{\circ} \mathrm{C}$. The optimum $\mathrm{pH}$ was determined by conducting assay at $60^{\circ} \mathrm{C}$ using appropriate buffers. The buffers used were citrate phosphate (Mcllvaine buffer) for $\mathrm{pH} 2.2-6$, sodium phosphate buffer $(\mathrm{pH} \mathrm{6-8)}$ and carbonatebicarbonate buffer (pH 9-10). The enzyme activity was calculated as a relative activity using the optimum condition as a reference of $100 \%$ activity. Thermostability of the purified BgcGC was evaluated by pre-incubating the enzyme at different temperature $\left(20-70^{\circ} \mathrm{C}\right)$ for 30 min prior to enzymatic assay. The $\mathrm{pH}$ stability was investigated by preincubating the enzyme at $4^{\circ} \mathrm{C}$ in buffer with different $\mathrm{pH}$ value (2-10) for $30 \mathrm{~min}$ prior to enzymatic assay. The residual activity for both parameters were determined under optimal assay conditions with the enzyme activity before pre-incubation regarded as $100 \%$.

The thermal inactivation of BgcGC was analysed by assaying the residual activity at the specific intervals after incubating the enzyme at different temperature $\left(20-70^{\circ} \mathrm{C}\right)$. In [residual activity] versus time was plotted according to the first-order kinetics [18]. Deactivation rate constant $\left(K_{d}\right)$ of irreversible thermal denaturation was obtained from the slope of the plot and used to calculate the halflife of thermal inactivation $\left(T_{1 / 2}\right)$, represented by $\ln _{2} / \mathrm{K}_{\mathrm{d}}$.

The effect of metal ions and additives on the enzyme activity were examined by adding the reagents to the assay reaction mixture at concentrations of 5,50 and $100 \mathrm{mM}$ for metal ions and $1 \%(\mathrm{v} / \mathrm{v})$ for additives. Enzyme activity was expressed as relative values (\%) with reference to the activity of the enzyme without metal ion or additive.

The substrate specificity was determined using potato galactan, lupin galactan, debranched arabinan, rhamnogalacturonan and pectin from apples as substrates. Michaelis-Menten equation was applied to calculate kinetic parameters $\left(\mathrm{V}_{\max }, \mathrm{K}_{\mathrm{m}}\right.$, $\mathrm{K}_{\text {cat }}$ and $\mathrm{K}_{\text {cat }} / \mathrm{K}_{\mathrm{m}}$ ) using Lineweaver-Burk plot.

\subsection{Extraction of Pectin from Sweet Potato Peels (SPP) and Monosaccharide Analysis}

Extraction of pectin from SPP was prepared as described previously with minor modifications [19]. Monosaccharides composition of the SPP pectin was identified using a modified method previous studies $[20,21]$. A $2.5 \mathrm{mg}$ SPP pectin was dissolved in $500 \mu \mathrm{l}$ of $2 M$ trifluoroacetic acid. The mixture was incubated at $95^{\circ} \mathrm{C}$ in a thermoblock (Thermomixer comfort; Eppendorf) for four hours for the hydrolysis to occur. Then, the remaining acid was dried in $70-80^{\circ} \mathrm{C}$ oven for overnight. The dried samples was re-dissolved in distilled water and filtered using Vivaspin 20, 30,000 MWCO PES (Sartorius Stedim Biotech $\mathrm{GmbH}$, Germany) to remove peptides and proteins. The samples were filtered using Vivaspin 20, $0.2 \mu \mathrm{m}$ PES (Sartorius Stedim Biotech $\mathrm{GmbH}$, Germany) prior to analysis using Bio-Rad Aminex HPX-87H (300 mm × 7.8 $\mathrm{mm}$; Bio-Rad, USA) column attached to a High Performance Liquid Chromatography (HPLC) (Agilent Infinity 1260, USA) equipped with refractive index (RI) detector. Rhamnose (Rha), galactose (Gal), galacturonic acid (GalA) and arabinose (Ara) were used as standard.

\subsection{Hydrolysis of SPP Pectin with BgcGC}

A $900 \mu \mathrm{l}$ of $10 \mathrm{mg} / \mathrm{ml}$ SPP pectin dissolved in $50 \mathrm{mM}$ sodium acetate buffer $\mathrm{pH} 5.5$ was added with $100 \mu \mathrm{l}$ endo-polygalacturonanase M2 (endo-PG) from Aspergillus aculeatus (Megazyme, Bray, Ireland) at a concentration of 40 units/g pectin, following procedure adapted from Khodaei \& Karboune (2013). The reaction was carried out at $35^{\circ} \mathrm{C}$ and 300 rpm for $20 \mathrm{hrs}$ in thermoblock before it was stopped by boiling for $5 \mathrm{~min}$. Then, $125 \mu$ lof the stopped reaction was added with BgcGC in accordance to beta-1,4-galactanase assay. 
Table 1 Purification table of two-step BgcGC purification scheme in E. coli

\begin{tabular}{|c|c|c|c|c|c|c|c|}
\hline Step & $\begin{array}{l}\text { Volume } \\
(\mathrm{ml})\end{array}$ & $\begin{array}{l}\text { Enzyme activity } \\
(\mathrm{U} / \mathrm{ml})\end{array}$ & $\begin{array}{l}\text { Total Activity } \\
\text { (U) }\end{array}$ & $\begin{array}{l}\text { Total protein } \\
\text { (mg) }\end{array}$ & $\begin{array}{c}\text { Specific activity } \\
\text { (U/mg) }\end{array}$ & $\begin{array}{l}\text { Purification } \\
\text { fold }\end{array}$ & Yield (\%) \\
\hline $\begin{array}{l}\text { Crude } \\
\text { extract }\end{array}$ & 20 & 13.0 & 259.9 & 90.7 & 2.9 & 1.0 & 100.0 \\
\hline Ni-NTA & 5 & 30.5 & 152.6 & 18.4 & 8.3 & 2.9 & 58.7 \\
\hline $\begin{array}{c}\text { Anion } \\
\text { exchange }\end{array}$ & 3 & 17.6 & 52.9 & 1.7 & 31.8 & 11.0 & 20.4 \\
\hline
\end{tabular}

\subsection{Galactooligosaccharide analysis using HPLC-UV}

A $10 \mu \mathrm{l}$ of sugar sample was added into $40 \mu \mathrm{l}$ labeling reagent $190 \mathrm{mg} / \mathrm{ml}$ 4-aminobenzoic acid methyl ester (ABEE) and $9 \mathrm{mg} / \mathrm{ml}$ sodium cyanoborohydrate dissolved in methanol:acetic acid;9:1). The mixture was heated in $85^{\circ} \mathrm{C}$ thermoblock for $45 \mathrm{~min}$ in a tightly closed container before $0.5 \mathrm{ml}$ water was added to the reaction mixture. Then, a $0.75 \mathrm{ml}$ diethyl ether was added, mixed and pipetted out to remove excess of 4-ABEE labeling. The washing step was repeated five times. The aqueous layer was lyophilized, and the residue was dissolved in a $100 \mu \mathrm{l}$ water and $100 \mu$ acetonitrile. The ABEE-derivatized sugars were filtered using 0.2 $\mathrm{mm}$-pore-sized syringe filter prior to injection into the HPLC system (Agilent Infinity 1260, USA) equipped with UV-Vis detector and an automatic injector. An XBridge ${ }^{\mathrm{TM}}$ Amide $5 \mu \mathrm{m}(4.6 \times 250 \mathrm{~mm}$; Waters, USA) column and the Guard Cartridge were employed for the sugar quantification. The analysis was monitored at $304 \mathrm{~nm}$ and the column was operated at $28^{\circ} \mathrm{C}$ under the gradient mode. The mobile phase used were Buffer A $120 \%$ of $100 \mathrm{mM}$ ammonium acetate buffer, $\mathrm{pH} 3.85,80 \%$ acetonitrile) and Buffer B $(20 \%$ of $100 \mathrm{mM}$ ammonium acetate buffer, $\mathrm{pH} 3.85,20 \%$ acetonitrile).

\subsection{RESULTS AND DISCUSSION}

\subsection{Sequence analysis of BgcGC}

A 2,355 nucleotides sequence encodes for a mature 785 amino acid (without its native 87 base pair signal peptide, predicted by SignalP server; http://www.cbs.dtu.dk/services/SignalP/) of beta-1,4galactanase gene from a thermophilic $G$. mahadii Geo-05 (GenBank: KY744702.1) was expressed, purified and characterized with codon optimization to achieve optimum expression of BgcGC in E. coli. The calculated molecular weight and pl for BgcGC was estimated to be $86.8 \mathrm{kDa}$ and 5.18 , respectively. BlastP program in the NCBI server (https://blast.ncbi.nlm.nih.gov/Blast.cgi) shows the highest identity of BgcGC protein sequence towards $\mathrm{GH}$ family 53 protein from Geobacillus sp. (75 - 100\%), followed by Bacillus sp. (63-67\%). BgcGC belongs to $\mathrm{GH}$ family 53 grouped under Clan $\mathrm{GH}-\mathrm{A}$, possess a $(\beta / \alpha)_{8}$ structure as the catalytic domain. Glu361 and
Glu479 as indicated in Figure 1 are the two catalytic residues of BgcGC that are conserved in other galactanases [23].

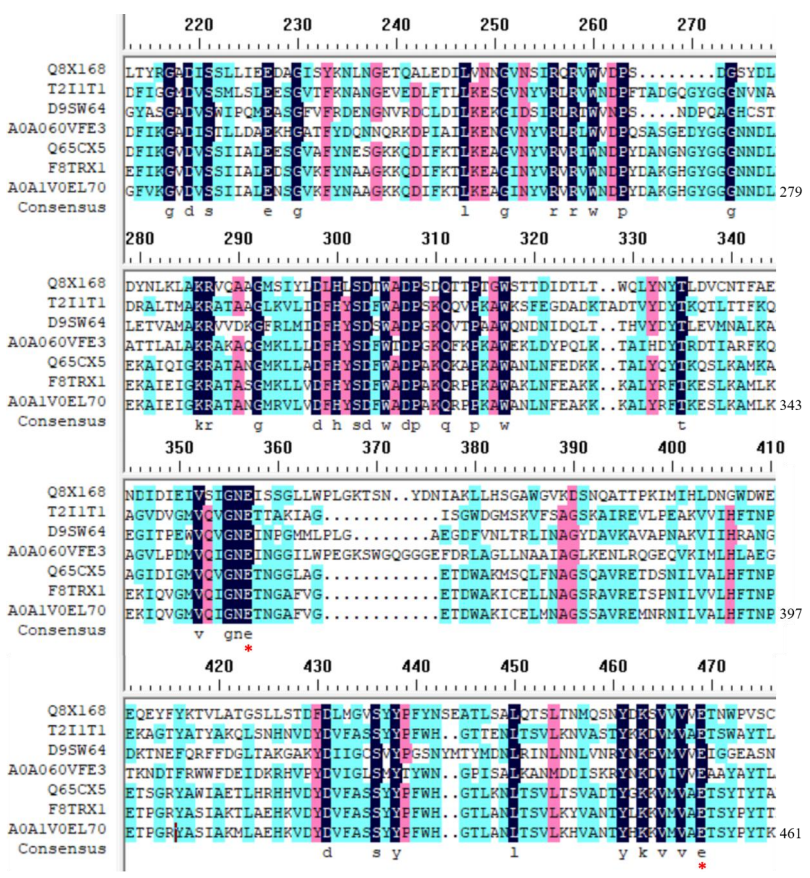

Figure 1 Protein alignment of the core region of catalytic domain between BgcGC and other bacterial and fungal galactanases. UniProtKB accession number represents the origin of the enzyme; Q8X168 (Aspergillus niger), T211T1 (Bifidobacterium longum), D9SW64 (Clostridium cellulovorans), A0A060VFE3 (Klebsiella pneumoniae), Q65CX5 (Bacillus licheniformis), F8TRX1 (G. stearothermophilus) and AOAIVOEL70 (G. mahadii). Conserved residues are shown on black background, while residues with high similarity are indicated on turquoise and magenta background. The catalytic residues of galactanase are marked below the sequence with a red star (E: Glutamate)

Bacterial galactanase was found to have longer loop region between the $\beta$ a motifs 7 and 8 compared to fungal galactanases [24]. Due to this, bacterial galactanases prone to hydrolyze longer oligosaccharides bind at -3 and -4 subsites. BgcGC was suggested to have this feature in accordance to beta-1,4-galactanase from $G$. stearothermophilus which shares $99.5 \%$ sequence identity [25]. However, recent study revealed a beta-1,4-galactanase from Bacteroides thetaiotaomicron resembled the fungal 
galactanase mode of action by acting on shorter GOS with degree of polymerization of three and less [9].

\subsection{Purification and biochemical characterization of BgcGC}

The recovery of purified BgcGC from two-step purification process was evaluated as listed in Table 1. A $20 \mathrm{ml}$ crude extract obtained from a $400 \mathrm{ml}$ culture gave a $20.4 \%$ yield of BgcGC with an increase in specific activity up to 11 -fold. An approximately 86.8 $\mathrm{kDa}$ of purified BgcGC was resolved as a single band on SDS-PAGE (Figure 2). Beta-1,4-galactanase from bacteria sp. has wide range of size from $40 \mathrm{kDa}$ [3] and can be up to $90 \mathrm{kDa}$ [26] compared to the one isolated from fungi (32-49 $\mathrm{kDa})$ [27].

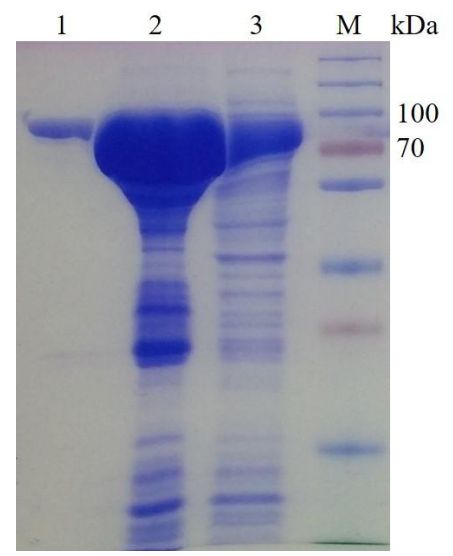

Figure 2 SDS-PAGE of a purified BgcGC ( $86.8 \mathrm{kDa})$. Lane 1: Purified BgcGC after two-steps purification, Lane 2: Concentrated BgcGC after first-step of Ni-NTA purification, Lane 3: Crude extract and Lane M: NEB protein marker

The purified BgcGC displayed optimum activity at $60^{\circ} \mathrm{C}$ and remained stable from $20-60^{\circ} \mathrm{C}$ with at least $60 \%$ of the activity retained after 30 min preincubation at the respective temperature (Figure 3a). BgcGC was derived from a thermophilic grampositive bacteria in Sungai Klah Hot Springs, Sungkai, Perak, Malaysia at $90^{\circ} \mathrm{C}$. Although the bacteria can grow up to $90^{\circ} \mathrm{C}$, it is not necessarily be the optimal temperature for the growth [28]. Besides, proteomic analysis of thermophiles exhibited noticeable proteins at significantly lower temperature than the optimal growth temperature [29]. The optimized codon applied for the synthesis of BgcGC might influence the enzyme thermal property. It was suggested the codon usage affect the translational rate of protein which subsequently influence structure arrangement and dynamic motion of the protein [30]. The optimum temperature of beta-1,4-galactanase can be as low as $37^{\circ} \mathrm{C}$ which originated from Bifidobacterium longum [26] and high as $90^{\circ} \mathrm{C}$ which originated from hyperthermophilic Thermotoga maritima [31]. Optimum pH for BgcGC was at 6 and stable at a wide range of $\mathrm{pH}$ from 4 to 10 (Figure $3 \mathrm{~b}$ ).
According to previous report, optimum $\mathrm{pH}$ for most of the bacterial galactanases were in a range of alkaline to neutral [5] compared to fungal galactanases which were more acidic [24, 10]. Variations in the amino acid compositions in the active site proved to have an influence in determining the optimum $\mathrm{pH}$ of the enzyme [32].
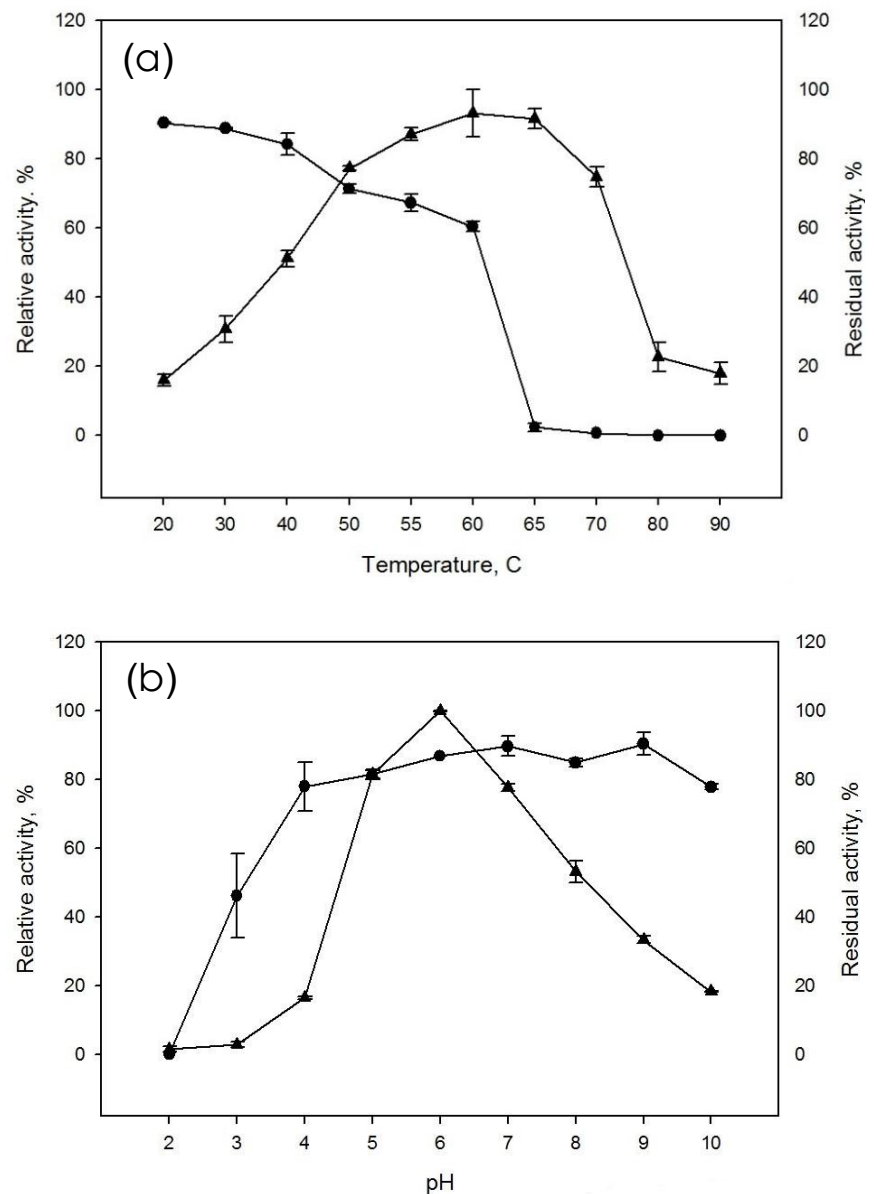

Figure 3 Effect of (a) temperature and, (b) $\mathrm{pH}$ on the purified BgcGC activity and stability. Error bars represent the standard deviations of triplicate experiments

Thermal inactivation of BgcGC revealed the half-life of the enzyme became shorter after prolonged exposure to higher temperature (Table 2). BgcGC managed to withstand $2.6 \mathrm{~min}$ at $70^{\circ} \mathrm{C}$ before the enzyme activity drastically reduced. At $60^{\circ} \mathrm{C}$, BgcGC half-life was about 35 min compared to beta-1,4-galactanase from Emericella nidulans, 10 min [10] and Talaromyces stipitatus, two min before increasing to $15 \mathrm{~min}$ after the mutation [33]. A delicate interaction of non-covalent forces such as hydrogen bonds, hydrophobic and Van der Waals interactions are holding the protein structure. When exposed to a high temperature, these interactions were disrupted and the protein slowly lose its native conformational form followed by aggregation and precipitation. Protein unfolding caused by heat usually is an irreversible reaction, however in certain cases reversible unfolding can be triggered by the 
presence of additive such as glycinamide and methanethiosulphonate [34, 35].

Table 2 Thermal deactivation constants $\left(K_{d}\right)$ and half-lives $\left(T_{1 / 2}\right)$ values at various temperatures.

\begin{tabular}{ccc}
\hline Temperature $\left({ }^{\circ} \mathbf{C}\right)$ & $\mathbf{K}_{\mathbf{d}}\left(\mathbf{m i n}^{-1}\right)$ & $\mathbf{T}_{\mathbf{1} / \mathbf{2}}(\mathbf{m i n})$ \\
\hline $\mathbf{2 0}$ & 0.0048 & 144.4 \\
\hline $\mathbf{3 0}$ & 0.0063 & 110.0 \\
\hline $\mathbf{4 0}$ & 0.0091 & 76.2 \\
\hline $\mathbf{5 0}$ & 0.0141 & 49.1 \\
\hline $\mathbf{6 0}$ & 0.0196 & 35.4 \\
\hline $\mathbf{7 0}$ & 0.2638 & 2.6 \\
\hline
\end{tabular}

In this study, BgcGC has been tested with several metal ions at various concentrations to investigate the possible inhibitory or stimulatory effect on the enzyme activity. Figure 4 shows BgcGC activity was severely affected at $5 \mathrm{mM} \mathrm{Fe}^{2+}$. Strong inhibiton caused by $\mathrm{Fe}^{2+}$ was also being observed in beta-1,4-galactanase from Aspergillus sojae [36] and Bacillus licheniformis [5]. BgcGC managed to maintain at least $88 \%$ of the activity in various concentrations of $\mathrm{K}^{+}$. Meanwhile, BgcGC activity demonstrated gradual decrease proportional with the increment of $\mathrm{Ca}^{2+}, \mathrm{Mg}^{2+}$ and $\mathrm{Mn}^{2+}$ concentrations. More than $65 \%$ of BgcGC activity was detected in 5 $\mathrm{mM} \mathrm{Co}{ }^{2+}, \mathrm{Cu}^{2+}$, and $\mathrm{Zn}^{2+}$. However, a sudden drop of activity was observed for these metal ions at 50 and $100 \mathrm{mM}$ concentrations. On the other hand, a slight increment ( $p>0.05$ ) of BgcGC activity was exhibited at $5 \mathrm{mM} \mathrm{Ni}^{2+}$ while higher concentrations abruptly affected the activity. Above all, BgcGC did not show a characteristic of a metalloenzyme or metalactivated enzyme as the activity was not dependent by the presence of metal ions.

According to Figure 5, adverse effect on BgcGC activity was contributed by sodium dodecyl sulphate (SDS) followed by PMSF. In contrast, ethylenediaminetetraacetic acid (EDTA), Tween-20 and 2-mercaptoethanol (2-ME) have no significant effect $(p>0.05)$ on the enzyme activity. Generally, SDS was known as a stronger detergent compared to Tween-20. Thus, dropped in BgcGC activity might be due to SDS molecules interfering with protein conformation and caused the enzyme to lose its active form [37].

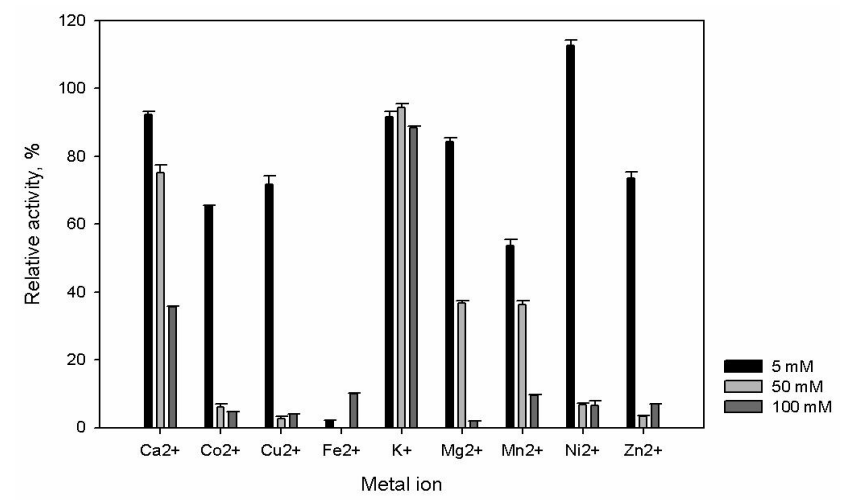

Figure 4 Effect of metal ions on BgcGC activity. Error bars represent the standard deviations of triplicate experiments

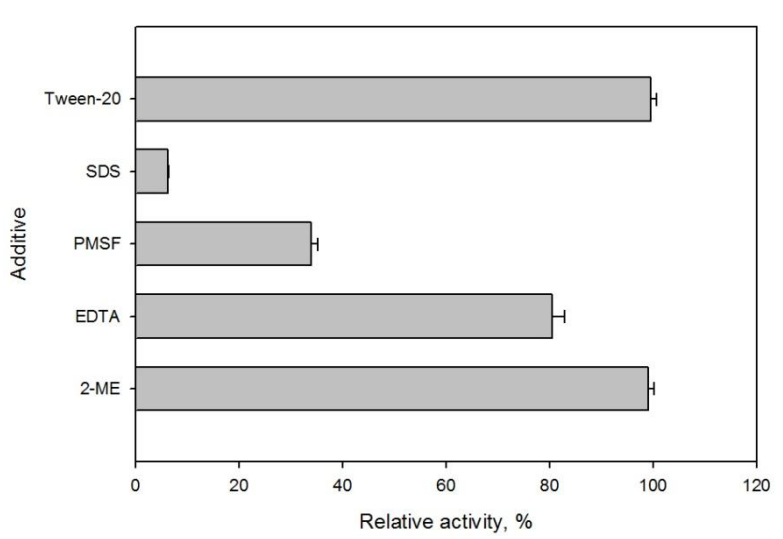

Figure 5 Effect of additives on BgcGC activity. Error bars represent the standard deviations of triplicate experiments

Michaelis-Menten enzyme kinetics were applied to evaluate BgcGC dynamics towards different substrate at various concentrations in standard activity assay. Table 3 shows reaction rate of BgcGC was higher for potato galactan as displayed by higher $V_{\max }\left(606.4 \mathrm{umol} \mathrm{mg}^{-1} \mathrm{~min}^{-1}\right.$ ) although the higher affinity was towards lupin galactan as revealed by lower $\mathrm{K}_{\mathrm{m}}$ value $\left(0.3 \mathrm{mg} \mathrm{m}^{-1}\right)$. $\mathrm{V}_{\max }$ and $\mathrm{K}_{\mathrm{m}}$ are independent as explained by $K_{m}=\left(k_{-1}+k_{2}\right) / k_{1}$ and $V_{m}=k_{2} *[E]_{0}$ equations. This means, $V_{\text {max }}$ is not directly related to $K_{m}$. $K_{m}$ values of $0.2 \mathrm{mg} / \mathrm{ml}$ [25] and 2.3 $\mathrm{mg} / \mathrm{ml}$ [5] were reported for galactanase against potato galactan. Nevertheless, higher turnover number, or $k_{\text {cat, }}$ was observed for potato galactan which implied more galactan was converted into product per second under optimal conditions compared to other substrates.

On the other hand, BgcGC hydrolyzed lupin galactan more efficiently than potato galactan as demonstrated by the higher enzyme efficiency value or $\mathrm{k}_{\mathrm{cat}} / \mathrm{K}_{\mathrm{m}}$. The difference of the catalytic efficiency between these two galactans is proposed due to their variation in sizes or structures. Galactose monomers that build up galactan are speculated to be in a linear form or consisted of branch. It is suggested that the galactan oligomer, as part of the pectin complex was influenced by the huge diversity of pectin structure and component which varies depending on the source, time of harvest and extraction method being used [38]. According to the manufacturer of the substrate, potato galactan was likely to be about $100 \mathrm{kDa}$ in size compared to 1182 $\mathrm{kDa}$ of lupin galactan. It is inferred that the substrate size caused the difference in the catalytic efficiency as happened to two subclasses of hydrolases although both enzymes cleave the C-N bond [39]. They claimed, increase in the molecular weight of substrate resulted in tighter binding and more efficient enzyme. BgcGC showed less binding affinity and catalytic efficiency towards debranched arabinan, rhamnogalacturonan and pectin. 
Table 3 BgcGC kinetic parameters for different substrates

\begin{tabular}{|c|c|c|c|c|}
\hline Substrate & $V_{\max }\left(\right.$ umol $\left.\mathrm{mg}^{-1} \mathrm{~min}^{-1}\right)$ & $\mathrm{K}_{\mathrm{m}}\left(\mathrm{mg} \mathrm{ml^{-1 }}\right)$ & $k_{\text {cat }}\left(s^{-1}\right)$ & $\mathrm{K}_{\text {cat }} / \mathrm{K}_{\mathrm{m}}\left(\mathrm{ml} \mathrm{mg}^{-1} \mathrm{~s}^{-1}\right)$ \\
\hline Potato galactan & 606.4 & 1.0 & 877.5 & 873.8 \\
\hline Lupin galactan & 402.4 & 0.3 & 582.3 & 1694.4 \\
\hline Debranched arabinan & 188.0 & 6.5 & 272.1 & 41.7 \\
\hline Rhamnogalacturonan I & 2.6 & 1.3 & 3.7 & 3.0 \\
\hline Pectin from apples & 87.3 & 5.1 & 126.4 & 24.8 \\
\hline
\end{tabular}

\subsection{Hydrolysis of SPP pectin by BgcGC}

The presence of galactan oligomer in the SPP pectin was suggested to be a part of rhamnogalacturonan I as confirmed by the detection of GalA, Gal, Rha and Ara (Figure 6). These sugars are the major constituent of rhamnogalacturonan I found in pectin extract from various plant sources such as potato pulp, pumpkin and ginseng [4, 40-42].

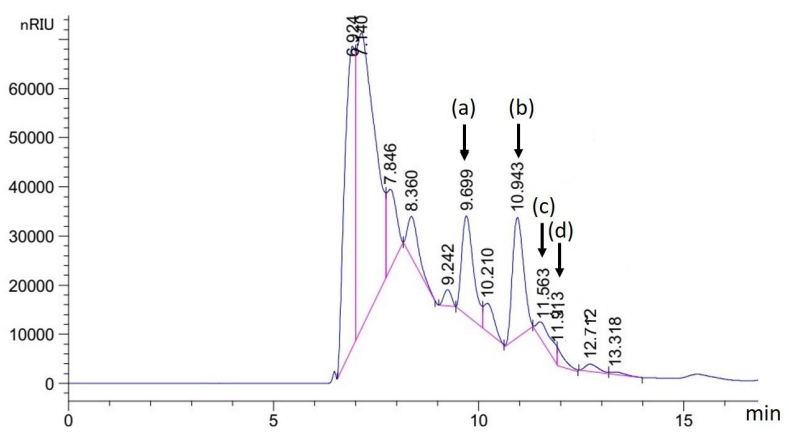

Figure 6 HLPC-RID chromatogram of monosaccharide composition of SPP pectin after performing TFA hydrolysis. Arrowed from left, a) GalA, b) Gal, c) Rha, d) Ara

Reaction of BgcGC towards the treated SPP pectin with endo-PG resulted in the production of galactose and GOS (Figure 7a). Neither galactose nor GOS was detected in SPP pectin treated with endo-PG alone (Figure 7b). This result indicates that the SPP pectin holds the galactose in the form of galactan oligomer. Thus, BgcGC plays an important role as one of the enzyme mixtures in pectin degradation.

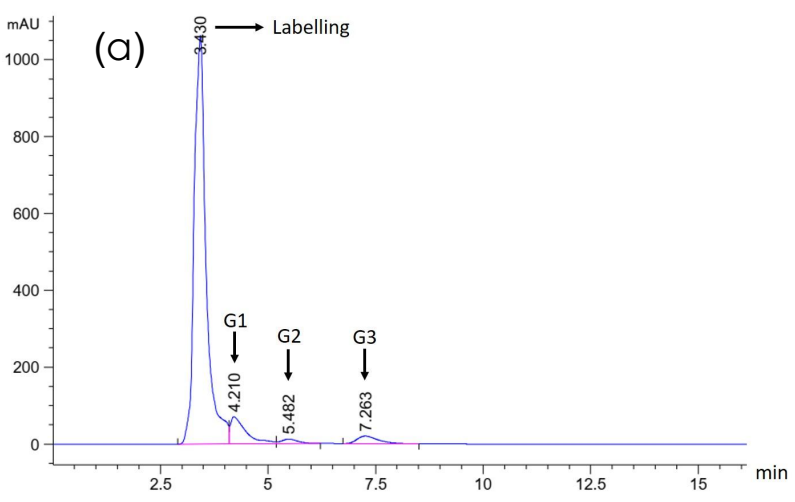

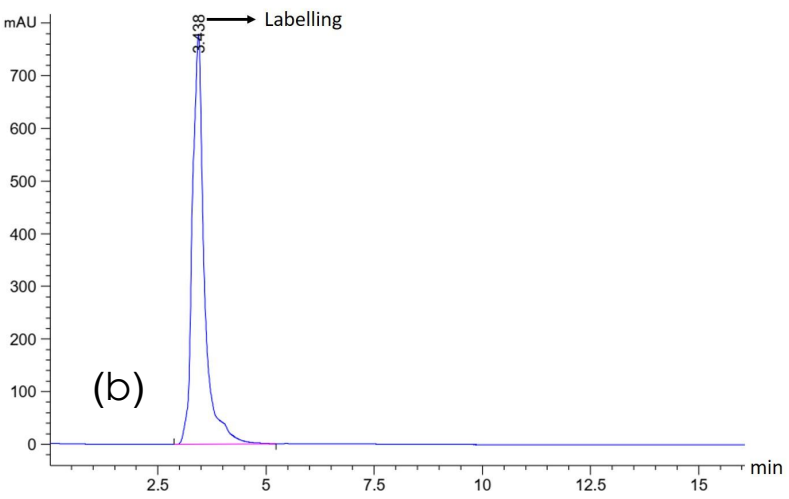

Figure 7 HLPC-UV chromatogram for GOS detection from treated SPP pectin sample with (a) Endo-PG and BgcGC, (b) Endo-PG. G1: Galactose, G2: Galactobiose, G3: Galactotriose, Labelling: ABEE labelling reagent

\subsection{CONCLUSION}

In summary, BgcGC has been characterized as a thermostable enzyme up to $60^{\circ} \mathrm{C}$ and possess a wide range of $\mathrm{pH}$ stability. This study also conveys the potential of BgcGC to be part of the collective enzymes working together in the degradation of complex pectin polysaccharide and produce specific targeted product of GOS.

\section{Acknowledgement}

This research was supported by the Fundamental Research Grant Scheme (Grant No. 4F993) through Universiti Teknologi Malaysia.

\section{References}

[1] Lombard, V., G. H. Ramulu, E. Drula, P. M. Coutinho and B. Henrissat. 2014. The Carbohydrate-Active Enzymes Database (CAZy) in 2013. Nucleic Acids Research. 42: 490-495. DOI : 10.1093/nar/gkt1 178.

[2] Watzlawick, H., K. M. Heravi and J. Altenbuchner. 2016. Role of the GanSPQAB Operon in Degradation of Galactan by Bacillus Subtilis. Journal of Biotechnology. 198(20): 2887-2896. DOI : 10.1128/JB.00468-16.

[3] Van Bueren, A. L., M. Mulder, S. Van Leeuwen and L. Dijkhuizen. 2017. Prebiotic Galactooligosaccharides Activate Mucin and Pectic Galactan Utilization Pathways in the Human Gut Symbiont Bacteroides 
Thetaiotaomicron. Scientific Reports. 7: 1-13. DOI: $10.1038 /$ srep40478.

[4] Khodaei, N. and S. Karboune. 2016. Enzymatic Generation of Galactose-rich Oligosaccharides/Oligomers from Potato Rhamnogalacturonan I Pectic Polysaccharides. Food Chemistry. 197: 406-414. DOI: 10.1016/j.foodchem.2015.10.122.

[5] de Lima, E. A., C. B. Machado, H. H. Sato and R. Ruller. 2016. GH53 Endo-Beta-1,4-Galactanase from a Newly Isolated Bacillus Licheniformis CBMAl 1609 as an Enzymatic Cocktail Supplement for Biomass Saccharification. Applied Biochemistry and Biotechnology. 179: 415-426. DOI: 10.1007/s12010-0162003-1.

[6] Ji, D., I. Sims, M. Xu, I. Stewart and D. Agyei. 2021. Production and Identification of GalactoOligosaccharides from Lactose Using $\beta$-DGalactosidases from Lactobacillus Leichmannii 313. Carbohydrate Polymer Technologies and Applications. 2: 100038. DOI: 10.1016/j.carpta.2021.100038.

[7] Fara, A., C. Sabater, J. Palacios, T. Requena, A. Montilla and G. Zárate. 2020. Prebiotic Galactooligosaccharides Production from Lactose and Lactulose by Lactobacillus Delbrueckii Subsp. Bulgaricus CRL450. Food and Function. 11: 5875-5886. DOI: 10.1039/d0fo00942c.

[8] Sabater, C., A. Fara, J. Palacios, N. Corzo, T. Requena, A. Montilla and G. Zárate. 2019. Synthesis of Prebiotic Galactooligosaccharides from Lactose and Lactulose by Dairy Propionibacteria. Food Microbiology. 77: 93105. DOI: 10.1016/j.fm.2018.08.014.

[9] Böger, M., J. Hekelaar, S. S. Van Leeuwen, L. Dijkhuizen, A. Lammerts and V. Bueren. 2019. Structural and Functional Characterization of a Family GH53 $\beta-1,4-$ Galactanase from Bacteroides Thetaiotaomicron That Facilitates Degradation of Prebiotic Galactooligosaccharides. Journal of Structural Biology. 205(1): 1-10. DOI: 10.1016/j.jsb.2018.12.002.

[10] Michalak, M., L. V. Thomassen, H. Roytio, A. C. Ouwehand, A. S. Meyer and J. D. Mikkelsen. 2012. Expression and Characterization of an Endo-1,4- $\beta$ Galactanase from Emericella Nidulans in Pichia Pastoris for Enzymatic Design of Potentially Prebiotic Oligosaccharides from Potato Galactans. Enzyme and Microbial Technology. 50: 121-129. DOI: 10.1016/j.enzmictec.2011.11.001.

[11] Atmodjo, M. A., Z. Hao and D. Mohnen. 2013. Evolving Views of Pectin Biosynthesis. Annual Review of Plant Biology. 64: 747-779. DOI: 10.1146/annurev-arplant042811-105534.

[12] Reichembach, L. H. and C. Lúcia de Oliveira Petkowicz. 2021. Pectins from Alternative Sources and Uses beyond Sweets and Jellies: An Overview. Food Hydrocolloids. 118: 106824. DOI: 10.1016/j.foodhyd.2021.106824.

[13] Satapathy, S., J. R. Rout, R. G. Kerry, H. Thatoi and S. L. Sahoo. 2020. Biochemical Prospects of Various Microbial Pectinase and Pectin: An Approachable Concept in Pharmaceutical Bioprocessing. Frontiers in Nutrition. 7(117): 1-17. DOI: 10.3389/fnut.2020.00117.

[14] Pacheco, M. T., M. Villamiel, R. Moreno and F. J. Moreno. 2019. Structural and Rheological Properties of Pectins Extracted from Industrial Sugar Beet By-Products. $\begin{array}{llll}\text { Molecules. } & \text { 24(392): }\end{array}$ 10.3390/molecules24030392

[15] Recombinant Protein and Purification Handbook: Principles and Methods. 2009. GE Healthcare.

[16] Lever, M. 1973. Calorimetric Determination and Acid Fluorometric with Hydrazide. Analytical Biochemistry. 7:
274-281. DOI: https://doi.org/10.1016/00062944(73)90083-5.

[17] Bradford, M. M. 1976. A Rapid and Sensitive Method for the Quantitation Microgram Quantities of Protein Utilizing the Principle of Protein-dye Binding. Analytical Biochemistry. $\quad 72$ : 248-254.

https://doi.org/10.1016/0003-2697(76)90527-3.

[18] Eze, S. O. O., F. C. Chilaka and B. C. Nwanguma. 2010. Studies on Thermodynamics and Kinetics of ThermoInactivation of Some Quality-Related Enzymes in White Yam (Dioscorea Rotundata). Journal of Thermodynamics \& Catalysis. 1(104): 1-5. DOI: 10.4172/2157-7544.1000104.

[19] Zaidel, D. N. A., N. N. Zainudin, Y. M. M. Jusoh and I. I. Muhamad. 2015. Extraction and Characterisation of Pectin from Sweet Potatot (Ipomoea Batatas) Pulp. Journal of Engineering Science and Technology. (3): 2229

[20] Soga, T. and D. N. Heiger. 1998. Simultaneous Determination of Monosaccharides in Glycoproteins by Capillary Electrophoresis. Analytical Biochemistry. 261: 73-78. DOI: 10.1006/abio.1998.2727.

[21] Wikiera, A., M. Mika, A. Starzyńska-Janiszewska and B. Stodolak. 2015. Development of Complete Hydrolysis of Pectins from Apple Pomace. Food Chemistry. 172: 675680. DOI: 10.1016/j.foodchem.2014.09.132.

[22] Khodaei, N. and S. Karboune. 2013. Extraction and Structural Characterisation of Rhamnogalacturonan IType Pectic Polysaccharides from Potato Cell Wall. Food Chemistry. 139: 617-23. DOI: 10.1016/j.foodchem.2013.01.110.

[23] Ryttersgaard, C., L. Lo Leggio, P. M. Coutinho, B. Henrissat and S. Larsen. 2002. Aspergillus Aculeatus Beta-1,4-Galactanase: Substrate Recognition and Relations to Other Glycoside Hydrolases in Clan GH-A. Biochemistry. 41: 15135-15143. DOI: https://doi.org/10.1021/bi026238c.

[24] Ryttersgaard, C., J. Le Nours, L. Lo Leggio, C. T. Jørgensen, L. L. H. Christensen, M. Bjørnvad and S. Larsen. 2004. The Structure of Endo-Beta-1,4Galactanase from Bacillus Licheniformis in Complex with Two Oligosaccharide Products. Journal of Molecular Biology. 341: 107-117. DOI: 10.1016/j.jmb.2004.05.017.

[25] Tabachnikov, O. and Y. Shoham. 2013. Functional Characterization of the Galactan Utilization System of Geobacillus Stearothermophilus. FEBS Journal. 280(3): 950-964. DOI: 10.1111 /febs.12089.

[26] Hinz, S. W. A., M. I. Pastink, L. A. M. Van Den Broek, J. P. Vincken and A. G. J. Voragen. 2005. Bifidobacterium Longum Endogalactanase Liberates Galactotriose from Type I Galactans. Applied and Environmental Microbiology. 71(9): 5501-5510. DOI: 10.1128/AEM.71.9.5501-5510.2005.

[27] Zavaleta, V. and J. Eyzaguirre. 2016. Penicillium Purpurogenum Produces a Highly Stable Endo- $\beta-(1,4)$ Galactanase. Applied Biochemistry and Biotechnology. 180: 1313-1327. DOI: 10.1007/s12010-016-2169-6.

[28] Wang, Z., W. Tong, Q. Wang, X. Bai, Z. Chen, J. Zhao, N. $X U$ and S. Liu. 2012. The Temperature Dependent Proteomic Analysis of Thermotoga Maritima. PLOS ONE. 7(10). DOI: 10.1371/journal.pone.0046463.

[29] Wang, Q., Z. Cen and J. Zhao. 2015. The Survival Mechanisms of Thermophiles at High Temperatures: An Angle of Omics. Physiology. 30: 97-106. DOI: 10.1152/physiol.00066.2013.

[30] Liu, L., L. Wang, Z. Zhang, S. Wang and H. Chen. 2012. Effect of Codon Message on Xylanase Thermal Activity. Journal of Biological Chemistry. 287(32): 27183-27188. 
DOI: $10.1074 / \mathrm{jbc} . M 111.327577$.

[31] Yang, $H ., H$. Ichinose, M. Yoshida, M. Nakajima, $H$. Kobayashi and S. Kaneko. 2006. Characterization of a Thermostable Endo- $\beta-1,4-D-G a l a c t a n a s e$ from the Hyperthermophile Thermotoga Maritima. Bioscience, Biotechnology, and Biochemistry. 70(2): 538-541. DOI: https://doi.org/10.1271/bbb.70.538.

[32] Le Nours, J., C. Ryttersgaard, L. Lo Leggio, P. R. Østergaard, T. V. Borchert, L. L. H. Christensen and S. Larsen. 2003. Structure of Two Fungal $\beta-1,4-$ Galactanases: Searching for the Basis for Temperature and $\mathrm{pH}$ Optimum. Protein Science. 12: 1195-1204. DOI: 10.1110/ps.0300103.

[33] Larsen, D. M., C. Nyffenegger, M. M. Swiniarska, A. Thygesen, M. L. Strube, A. S. Meyer and J. D. Mikkelsen. 2015. Thermostability Enhancement of an Endo-1,4- $\beta$ Galactanase from Talaromyces Stipitatus by SiteDirected Mutagenesis. Applied Microbiology and Biotechnology. 99(10): 4245-4253. DOI: 10.1007/s00253014-6244-z.

[34] Tomita, S. and K. Shiraki. 2011. Why Do Solution Additives Suppress the Heat-induced Inactivation of Proteins? Inhibition of Chemical Modifications. Biotechnology Progress. 27(3): 855-862. DOI: 10.1002/btpr.597.

[35] Futami, J., A. Miyamoto, A. Hagimoto, S. Suzuki, M. Futami and T. Hiroko. 2017. Evaluation of Irreversible Protein Thermal Inactivation Caused by Breakage of Disulphide Bonds Using Methanethiosulphonate. Scientific Reports. 7(12471): 1-10. DOI: 10.1038/s41598017-12748-y.

[36] Kimura, I., N. Yoshioka and S. Tajima. 1998. Purification and Characterization of an Endo-1,4- $\beta-D-G a l a c t a n a s e$ from Aspergillus Sojae. Journal of Fermentation and Bioengineering. 85(1): 48-52. DOI: https://doi.org/10.1016/\$0922-338X(97)80352-2.

[37] Bhuyan, A. K.. 2009. On the Mechanism of SDS-Induced Protein Denaturation on the Mechanism of SDS-Induced Protein Denaturation. Biopolymers. 93(2): 186-199. DOI: 10.1002/bip.21318.

[38] Gawkowska, D., J. Cybulska and A. Zdunek. 2018. Structure-Related Gelling of Pectins and Linking with Other Natural Compounds: A Review. Polymers. 10(762): 1-25. DOI: 10.3390/polym10070762.

[39] Sousa, S. F., M. J. Ramos, C. Lim and P. A. Fernandes. 2015. Relationship between Enzyme / Substrate Properties and Enzyme Efficiency in Hydrolases. ACS Catalysis. 5(10): 5877-5887. DOI: 10.1021/acscatal.5b00923.

[40] Yang, J., T. Mu and M. Ma. 2018. Extraction, Structure, and Emulsifying Properties of Pectin from Potato Pulp. Food Chemistry. 244: 197-205. DOI: 10.1016/j.foodchem.2017.10.059.

[41] Zhao, J., F. Zhang, X. Liu, K. St and A. Zhang. 2017. Isolation of a Lectin Binding Rhamnogalacturonan-I Containing Pectic Polysaccharide from Pumpkin. Carbohydrate Polymers. 163: 330-336. DOI: 10.1016/j.carbpol.2017.01.067.

[42] Sun, L., D. Ropartz, L. Cui, H. Shi, M. C. Ralet and Y. Zhou. 2019. Structural Characterization of Rhamnogalacturonan Domains from Panax Ginseng C. A. Meyer. Carbohydrate Polymers. 203: 119-127. DOI: 10.1016/j.carbpol.2018.09.045. 